\title{
Adsorption Behavior of Trace Beryllium (II) onto Metal Oxide Nanoparticles Dispersed in Water
}

\author{
Shoichi Katsuta ${ }^{1}$, Naoki Kanaya ${ }^{1}$, Kotaro Bessho ${ }^{2}$, Hideaki Monjushiro ${ }^{2}$ \\ ${ }^{1}$ Graduate School of Science, Chiba University, Chiba, Japan \\ ${ }^{2}$ Radiation Science Center, High Energy Accelerator Research Organization (KEK), Tsukuba, Japan \\ Correspondence: Shoichi Katsuta, Graduate School of Science, Chiba University, 1-33 Yayoi-cho, Inage, Chiba \\ 263-8522, Japan. E-mail: katsuta@faculty.chiba-u.jp; Kotaro Bessho, Radiation Science Center, High Energy \\ Accelerator Research Organization (KEK), 1-1 Oho, Tsukuba, Ibaraki 305-0801, Japan. E-mail: kotaro.bessho@kek.jp
}

Received: August 21, 2017 Accepted: September 25, 2017 Online Published: October 8, 2017

doi:10.5539/ijc.v9n4p62

URL: https://doi.org/10.5539/ijc.v9n4p62

\begin{abstract}
Radioactive trace ${ }^{7} \mathrm{Be}$ produced in cooling water systems for high-energy accelerators is known to be captured by metal-oxide colloidal nanoparticles generated through corrosion of metal components in water. This study is aimed at investigating the adsorption behavior of trace $\mathrm{Be}^{2+}$ onto various oxide nanoparticles $\left(\mathrm{Al}_{2} \mathrm{O}_{3}, \mathrm{SiO}_{2}, \mathrm{TiO}_{2}, \mathrm{Fe}_{2} \mathrm{O}_{3}, \mathrm{CoO}\right.$, and $\mathrm{CuO}$ ) dispersed in water at $25^{\circ} \mathrm{C}$ in order to clarify the tendency and features of the interaction of Be ${ }^{2+}$ with metal oxides. From $\mathrm{pH}$ dependence of the distribution ratio of $\mathrm{Be}^{2+}$ between the nanoparticle phase and the aqueous solution phase, the surface complexation constants $\left(\beta_{\mathrm{s}, n}\right)$ have been determined for the reaction of $\mathrm{Be}^{2+}$ with the hydroxyl groups on the oxide surface $(>\mathrm{S}-\mathrm{OH})$, i.e., $\mathrm{Be}^{2+}+n>\mathrm{S}-\mathrm{OH} \rightleftarrows(>\mathrm{S}-\mathrm{O})_{n} \mathrm{Be}^{(2-n)^{+}}+n \mathrm{H}^{+}$. The $n$ values are generally 1 and 2 and the sequences of the $\beta_{\mathrm{s}, n}$ values are $\mathrm{Fe}_{2} \mathrm{O}_{3}>\mathrm{TiO}_{2} \approx \mathrm{Al}_{2} \mathrm{O}_{3}>\mathrm{SiO}_{2}$ for $\beta_{\mathrm{s}, 1}$ and $\mathrm{Fe}_{2} \mathrm{O}_{3}>\mathrm{TiO}_{2}>\mathrm{SiO}_{2}>\mathrm{Al}_{2} \mathrm{O}_{3}>>\mathrm{CoO}_{2} \approx$ $\mathrm{CuO}$ for $\beta_{\mathrm{s}, 2}$. The dependences of the the $\beta_{\mathrm{s}, n}$ values on the kind of oxide are explained based on the electronegativity of the metal (or $\mathrm{Si}$ ) composing the oxide.
\end{abstract}

Keywords: colloid, nanoparticle, metal oxide, beryllium (II), surface complexation

\section{Introduction}

Metal oxide nanoparticles have been widely studied as functional materials for photocatalyst, battery, paint, antibacterial agent, cosmetic and skin care products, and so on (Linsebigler, Lu, \& Yates, 1995; Poizot, Laruelle, Grugeon, Dupont, \& Tarascon, 2000; Fernández-García, Martínez-Arias, Hanson, \& Rodríguez, 2004; Carpenter, Mathur, \& Kolmakov, 2013). Recently, they also attract attention as adsorbents for heavy metal ions (Hua et al., 2012; Cao et al., 2012; Al-Saad et al., 2012; Mahdavi, Jalali, \& Afkhami, 2012; Schilz et al., 2015; Taman, Ossman, Mansour, \& Farag, 2015; Vélez et al., 2016; Sadegh et al., 2017). On the other hand, metal oxides are naturally present as colloidal nanoparticles in aquatic systems and play an important role in the distribution and diffusion of trace metals in the environment (Brown \& Parks, 2001). The mechanism of the adsorption of metal ions on metal oxides is generally explained by complex formation between the surface hydroxyl groups of the oxides and the metal ions in water (Balistrieri, Brewer, \& Murray, 1981; Stumm et al., 1987; Rahnemaie, Hiemstra, \& Van Riemsdijk, 2006; Sverjensky, 2006).

In cooling water systems for high-energy particle accelerators, beryllium-7 $\left({ }^{7} \mathrm{Be}\right)$ is produced due to nuclear reactions under an intense radiation field. It is important to know the behavior of radioactive and trace ${ }^{7} \mathrm{Be}$ in the cooling water. In recent studies, a large part of ${ }^{7} \mathrm{Be}$ was found to be captured by metal-oxide colloidal nanoparticles generated through corrosion of metal components in water (Itoh et al., 1998, 1999; Matsumura et al., 2009; Bessho et al., 2010; Bessho et al., 2013; Matsumura et al., 2014; Bessho et al., 2015a; Bessho, Matsumura, Takahashi, \& Masumoto, 2015b). On the other hand, the adsorption behavior of trace $\mathrm{Be}^{2+}$ onto $\mathrm{CuO}$ nanoparticles in water was evaluated and the complexation constants between $\mathrm{Be}^{2+}$ and the surface hydroxyl groups of $\mathrm{CuO}$ were determined (Bessho, Kanaya, Shimada, Katsuta, $\&$ Monjushiro, 2014). In order to clarify the tendency and features of the interaction of $\mathrm{Be}^{2+}$ with metal oxides, it is further necessary to determine and compare the surface complexation constants for various oxides.

In this paper, we report the adsorption behavior of trace $\mathrm{Be}^{2+}$ onto nanoparticles of $\mathrm{Al}_{2} \mathrm{O}_{3}, \mathrm{SiO}_{2}, \mathrm{TiO}_{2}, \mathrm{Fe}_{2} \mathrm{O}_{3}, \mathrm{CoO}$, and $\mathrm{CuO}$ in water at $25^{\circ} \mathrm{C}$. The distribution ratio of $\mathrm{Be}^{2+}$ between the nanoparticle phase and the aqueous solution phase is measured as a function of aqueous $\mathrm{pH}$, and the complexation equilibria between $\mathrm{Be}^{2+}$ and the surface hydroxyl groups 
are analyzed. Based on the complexation constants, the factors governing the interaction of $\mathrm{Be}^{2+}$ with metal oxides are discussed.

\section{Experiment}

\subsection{Reagents}

Nanoparticles of $\mathrm{Al}_{2} \mathrm{O}_{3}, \mathrm{SiO}_{2}, \mathrm{TiO}_{2}, \mathrm{Fe}_{2} \mathrm{O}_{3}$, and $\mathrm{CoO}$ were purchased from C. I. Kasei. Co., Ltd. and used without further purification. The purities are shown in Table 1. Aqueous standard solutions of $\mathrm{Be}^{2+}$ were purchased from Kanto Chemical as $1000 \mathrm{mg} / \mathrm{L}$ atomic absorption standards and were used after appropriate dilution. Water was deionized with Milli-Q Labo system (Millipore) just before use. Analytical grade potassium hydrogen phthalate was dried at $110{ }^{\circ} \mathrm{C}$ for $4 \mathrm{~h}$ before use as a standard for acid-base titrations. Other chemicals were purchased as analytical grade reagents and used without further purification.

\subsection{Characterization of Nanoparticles Dispersed in Water}

The hydroxyl group concentration per unit mass of the oxide nanoparticles was determined in the same manner as described previously (Bessho et al., 2014). Briefly, $\mathrm{pH}$ titrations were performed by adding aliquots of a standardized aqueous $\mathrm{NaOH}$ solution to the nanoparticles $(500 \mathrm{mg})$ - water $\left(50 \mathrm{~cm}^{3}\right)$ suspension at a constant temperature $(25 \pm$ $0.2^{\circ} \mathrm{C}$ ); the $\mathrm{pH}$ was measured with a HM-20S digital $\mathrm{pH}$ meter (DKK-TOA) equipped with a glass electrode. The examples of the titration curves are shown in Figure 1. After the equivalence point where the hydroxyl groups are fully dissociated, the shape of the titration curve for the aqueous nanoparticle suspension should be the same as that for the blank in the absence of the nanoparticles; from the rightward shift of the titration curve from the blank to the suspension, the amount of the hydroxyl groups of the nanoparticles was determined. For reference, the equivalence points calculated from the amount of the hydroxyl groups are shown by dotted lines in Figure 1.

The zeta potential and particle size distribution of the oxide nanoparticles dispersed in water were measured by laser Doppler electrophoresis and dynamic light scattering, respectively, using a SZ-100 nanoparticle analyzer (Horiba) at room temperature. For the zeta potential measurements, aqueous suspensions of $\mathrm{Al}_{2} \mathrm{O}_{3}\left(100 \mathrm{mg} / \mathrm{dm}^{3}\right), \mathrm{SiO}_{2}(200$ $\left.\mathrm{mg} / \mathrm{dm}^{3}\right), \mathrm{TiO}_{2}\left(200 \mathrm{mg} / \mathrm{dm}^{3}\right), \mathrm{Fe}_{2} \mathrm{O}_{3}\left(200 \mathrm{mg} / \mathrm{dm}^{3}\right)$, and $\mathrm{CoO}\left(180 \mathrm{mg} / \mathrm{dm}^{3}\right)$ were prepared. The $\mathrm{pH}$ of each solution was adjusted with $3 \times 10^{-4} \mathrm{~mol} / \mathrm{dm}^{3} \mathrm{HCl}\left(\mathrm{pH} \mathrm{3.6)}, 1.5 \times 10^{-2} \mathrm{~mol} / \mathrm{dm}^{3}\right.$ potassium hydrogen phthalate $-\mathrm{HCl}$ buffer $(\mathrm{pH} 4.1)$,
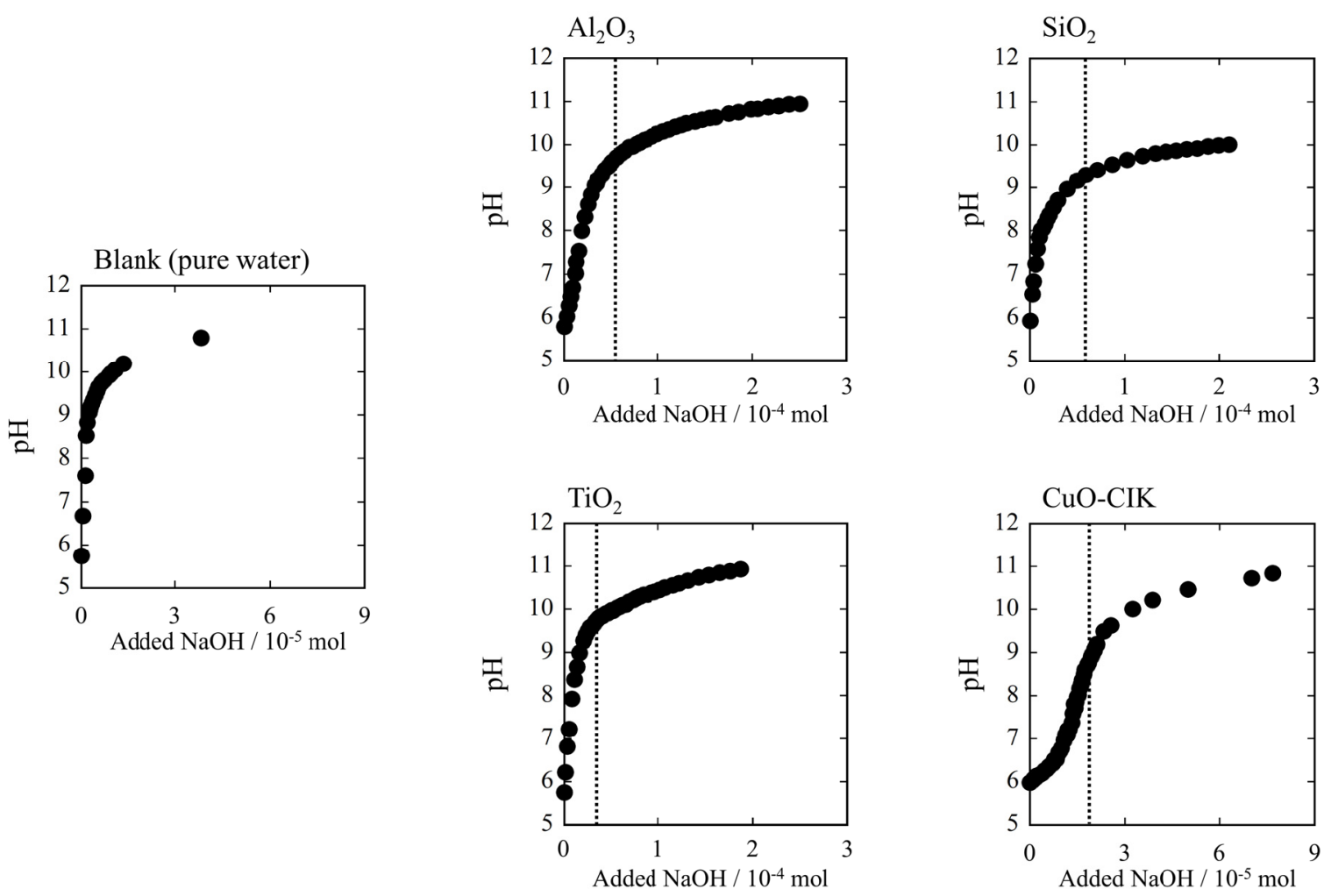

Figure 1. Titration curves for aqueous nanoparticle suspensions of $\mathrm{Al}_{2} \mathrm{O}_{3}, \mathrm{SiO}_{2}, \mathrm{TiO}_{2}$, and $\mathrm{Fe}_{2} \mathrm{O}_{3}(500 \mathrm{mg} / 50$ $\left.\mathrm{cm}^{3}\right)$ and pure water (blank) with an aqueous $\mathrm{NaOH}$ solution $\left(1.1 \times 10^{-2} \mathrm{~mol} / \mathrm{dm}^{3}\right)$. The dotted vertical lines indicate the equivalence points calculated from the hydroxyl group concentrations (Table 1). 
$5 \times 10^{-3} \mathrm{~mol} / \mathrm{dm}^{3} \mathrm{CH}_{3} \mathrm{COOH}-\mathrm{CH}_{3} \mathrm{COONa}$ buffer (pH 4.7), $1 \times 10^{-2} \mathrm{~mol} / \mathrm{dm}^{3}$ 2-morpholinoethanesulfonic acid (MES) $-\mathrm{NaOH}$ buffer (pH 5.5 to 6.7), $2 \times 10^{-3} \mathrm{~mol} / \mathrm{dm}^{3}$ piperazine-1,4-bis(2-ethanesulfonic acid) (PIPES) $-\mathrm{NaOH}$ buffer (pH 7.2), $1 \times 10^{-3}$ to $2 \times 10^{-2} \mathrm{~mol} / \mathrm{dm}^{3} \mathrm{NH}_{3}-\mathrm{NH}_{4} \mathrm{Cl}$ buffer ( $\mathrm{pH} 7.9$ to 10.2 ), or $1 \times 10^{-3} \mathrm{~mol} / \mathrm{dm}^{3} \mathrm{NaOH}(\mathrm{pH} 10.9$ ), and the ionic strength was adjusted to 0.01 with $\mathrm{NaNO}_{3}$. The cells used for zeta potential measurements were carbon electrode cells and the voltage applied to the electrodes was set to $3.4 \mathrm{~V}$. The particle size measurements were done for aqueous suspensions of $\mathrm{Al}_{2} \mathrm{O}_{3}\left(100 \mathrm{mg} / \mathrm{dm}^{3}\right), \mathrm{SiO}_{2}\left(150 \mathrm{mg} / \mathrm{dm}^{3}\right), \mathrm{TiO}_{2}\left(25 \mathrm{mg} / \mathrm{dm}^{3}\right), \mathrm{Fe}_{2} \mathrm{O}_{3}\left(60 \mathrm{mg} / \mathrm{dm}^{3}\right)$, and $\mathrm{CoO}\left(60 \mathrm{mg} / \mathrm{dm}^{3}\right)$. A 1-cm square plastic cell was used and the scattered light was collected by a detector with $90^{\circ}$ scattering angle.

\subsection{Adsorption Experiments of $\mathrm{Be}^{2+}$}

Aqueous solutions containing $1.0 \times 10^{-7} \mathrm{~mol} / \mathrm{dm}^{3} \mathrm{Be}^{2+}$ were prepared. The $\mathrm{pH}$ of each solution was adjusted with $5 \times$ $10^{-3} \mathrm{~mol} / \mathrm{dm}^{3} \mathrm{CH}_{3} \mathrm{COOH}-\mathrm{CH}_{3} \mathrm{COONa}$ buffer (pH 3.7 to 5.3) or $1 \times 10^{-2} \mathrm{~mol} / \mathrm{dm}^{3} \mathrm{MES}-\mathrm{NaOH}$ buffer (pH 5.3 to 6.5). Ionic strength was adjusted to 0.01 with $\mathrm{NaNO}_{3}$. The buffer solution of $\mathrm{Be}^{2+}\left(20 \mathrm{~cm}^{3}\right)$ was mixed with nanoparticles of an oxide $(0.001$ to $0.02 \mathrm{~g})$ in a plastic vial. Equilibration of the system was done by shaking the vial for $48 \mathrm{~h}$ with an Eyela SS-8 shaker in an Eyela SB-24 water bath $\left(25 \pm 0.2{ }^{\circ} \mathrm{C}\right)$. The nanoparticles were removed from the system by centrifugation at $15000 \mathrm{rpm}$ with a Kubota 3700 centrifuge. The concentration of $\mathrm{Be}^{2+}$ in the aqueous phase was determined by graphite furnace atomic absorption spectrometry with a Z-5000 polarized Zeeman atomic absorption spectrometer (Hitachi), and the distribution ratio of $\mathrm{Be}^{2+}$ between the nanoparticle phase and the aqueous solution phase was calculated. The $\mathrm{pH}$ of the aqueous phase was also measured with a glass electrode.

\section{Results and Discussion}

\subsection{Fundamental Properties of Nanoparticles Dispersed in Water}

Fundamental physical parameters (under dry conditions) of the oxide nanoparticles used in this study were specified by the manufacturer. The zeta potentials, average particle size, and hydroxyl group concentrations were determined for the nanoparticles in an aqueous suspension state. These data, except for the zeta potentials, are summarized in Table 1. All the oxides dispersed in water are 5 to 10 times greater in the average particle size than those in dry state, showing some aggregation of the nanoparticles in the solution.

Table 1. Physical properties of oxide nanoparticles

\begin{tabular}{|c|c|c|c|c|c|c|}
\hline & $\mathrm{Al}_{2} \mathrm{O}_{3}$ & $\mathrm{SiO}_{2}$ & $\mathrm{TiO}_{2}$ & $\mathrm{Fe}_{2} \mathrm{O}_{3}$ & $\mathrm{CoO}$ & $\mathrm{CuO}$ \\
\hline Purity $^{a}(\%)$ & 99.9 & 99.9 & 99.8 & 99.5 & 99.5 & 99.9 \\
\hline Density ${ }^{\mathrm{a}}\left(\mathrm{g} / \mathrm{cm}^{3}\right)$ & 3.5 & 2.2 & 3.7 & 5.1 & 5.4 & 6.3 \\
\hline Average particle size $(\text { dry })^{\mathrm{a}}(\mathrm{nm})$ & 31 & 25 & 36 & 39 & 22 & 48 \\
\hline Average particle size $(\text { wet })^{b}(\mathrm{~nm})$ & $170 \pm 20$ & $250 \pm 30$ & $430 \pm 60$ & $310 \pm 30$ & $270 \pm 80$ & $600^{\mathrm{c}}$ \\
\hline$-\mathrm{OH}$ concentration $(\mathrm{mol} / \mathrm{g})$ & $\begin{array}{c}(1.09 \pm 0.08) \\
\times 10^{-4}\end{array}$ & $\begin{array}{c}(1.2 \pm 0.2) \\
\times 10^{-4}\end{array}$ & $\begin{array}{c}(7.2 \pm 0.4) \\
\times 10^{-5}\end{array}$ & $\begin{array}{c}(4.9 \pm 0.4) \\
\times 10^{-5}\end{array}$ & $\begin{array}{c}(1.83 \pm 0.02) \\
\times 10^{-4}\end{array}$ & $3.7 \times 10^{-5 \mathrm{c}}$ \\
\hline
\end{tabular}

a. Manufacturer's data for dry nanoparticles.

b. Obtained for nanoparticles dispersed in water ( $\mathrm{pH}$ 5.5).

c. Bessho et al., 2014.

In Figure 2, the zeta potentials of the five kinds of oxide nanoparticles are shown as a function of $\mathrm{pH}$ at a constant ionic strength of 0.01 . In all cases, the zeta potential shows a continuous decrease with $\mathrm{pH}$. Under the same $\mathrm{pH}$ condition as that of the adsorption experiments ( $\mathrm{pH} 3.7$ to 6.5), the zeta potential value differs depending on the kind of oxide: $\mathrm{Al}_{2} \mathrm{O}_{3}$ (positive) $>\mathrm{CoO}$ and $\mathrm{CuO}$ (positive $\sim$ neutral) $>\mathrm{TiO}_{2}$ (positive $\sim$ neutral $\sim$ negative) $>\mathrm{SiO}_{2}$ and $\mathrm{Fe}_{2} \mathrm{O}_{3}$ (negative). Such a difference in the zeta potential may reflect the amount of the hydroxyl groups dissociated or protonated. However, as seen from the $\mathrm{pH}$ titration curves (Figure 1), the degree of dissociation of the hydroxyl groups is small for all the oxides in this $\mathrm{pH}$ region. 

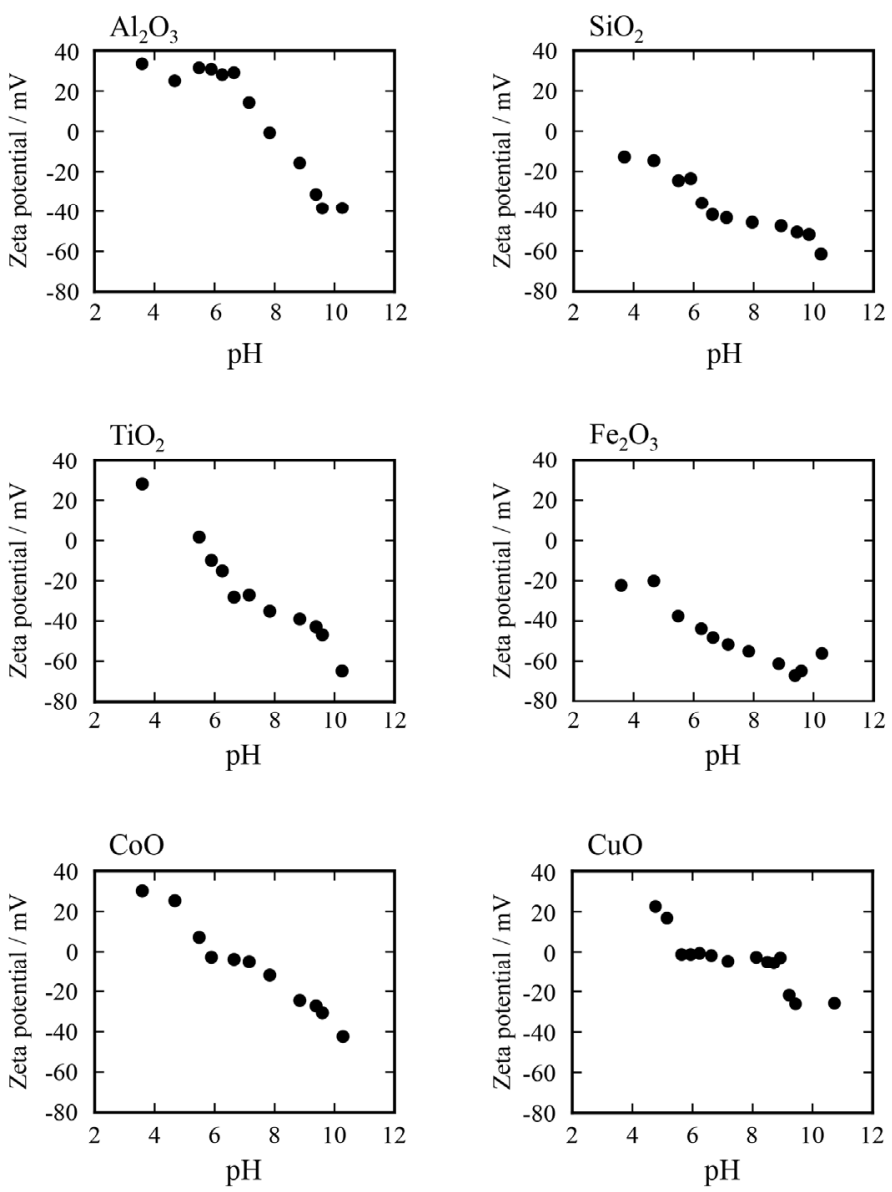

Figure 2. Zeta potential versus $\mathrm{pH}$ plots for oxide nanoparticles dispersed in water $\left(\mathrm{Al}_{2} \mathrm{O}_{3}, 100 \mathrm{mg} / \mathrm{dm}^{3} ; \mathrm{SiO}_{2}, \mathrm{TiO}_{2}\right.$, $\left.\mathrm{Fe}_{2} \mathrm{O}_{3}, 200 \mathrm{mg} / \mathrm{dm}^{3} ; \mathrm{CoO}, 180 \mathrm{mg} / \mathrm{dm}^{3}\right)$ at a constant ionic strength $\left(0.01 \mathrm{~mol} / \mathrm{dm}^{3}\right)$

\subsection{Adsorption Behavior of $\mathrm{Be}^{2+}$ in Nanoparticle Dispersed Aqueous Solution}

The partitioning of $\mathrm{Be}^{2+}$ between the nanoparticle phase and the aqueous solution phase was evaluated in terms of the distribution ratio $(D)$ defined by Equation (1):

$$
D=\{\text { concentration of Be in nanoparticles }(\mathrm{mol} / \mathrm{g})\} /\left\{\text { concentration of Be in aqueous solution }\left(\mathrm{mol} / \mathrm{dm}^{3}\right)\right\} \text {. }
$$

In Figure 3, logarithmic values of $D$ are shown as a function of $\mathrm{pH}$. For all the metal oxides, the $\log D$ value increases with increasing $\mathrm{pH}$. The $D$ value at $\mathrm{pH} 6.0$ varies in the order, $\mathrm{TiO}_{2} \approx \mathrm{SiO}_{2} \approx \mathrm{Fe}_{2} \mathrm{O}_{3}>\mathrm{Al}_{2} \mathrm{O}_{3}>\mathrm{CuO}>>\mathrm{CoO}$, where the $D$ value for $\mathrm{CuO}$ is cited from the literature (Bessho et al., 2014). As an overall tendency, the $D$ value is larger for the oxide in which the metal (including $\mathrm{Si}$ ) has a higher valence. This order is not consistent with that of the hydroxyl group concentration (mol/g) of the oxides, i.e., $\mathrm{CoO}>\mathrm{SiO}_{2} \approx \mathrm{Al}_{2} \mathrm{O}_{3}>\mathrm{TiO}_{2}>\mathrm{Fe}_{2} \mathrm{O}_{3}>\mathrm{CuO}$ (Table 1).

The adsorption of $\mathrm{Be}^{2+}$ onto the oxide nanoparticles was evaluated based on the surface complexation model, in which the surface hydroxyl groups on the oxide deprotonate and form complexes with $\mathrm{Be}^{2+}$ in water. The complexation equilibrium can be written as follows (Bessho et al., 2014).

$$
\mathrm{Be}^{2+}+n>\mathrm{S}-\mathrm{OH} \rightleftarrows(>\mathrm{S}-\mathrm{O})_{n} \mathrm{Be}^{(2-n)+}+n \mathrm{H}^{+} .
$$

The surface complexation constants $\left(\beta_{\mathrm{s}, n}\right)$ are defined by Equation (3):

$$
\beta_{\mathrm{s}, n}=\left[(>\mathrm{S}-\mathrm{O})_{n} \mathrm{Be}^{(2-n)+}\right]_{\mathrm{s}}\left[\mathrm{H}^{+}\right]^{n} /\left(\left[\mathrm{Be}^{2+}\right][>\mathrm{S}-\mathrm{OH}]_{\mathrm{s}}{ }^{n}\right) .
$$




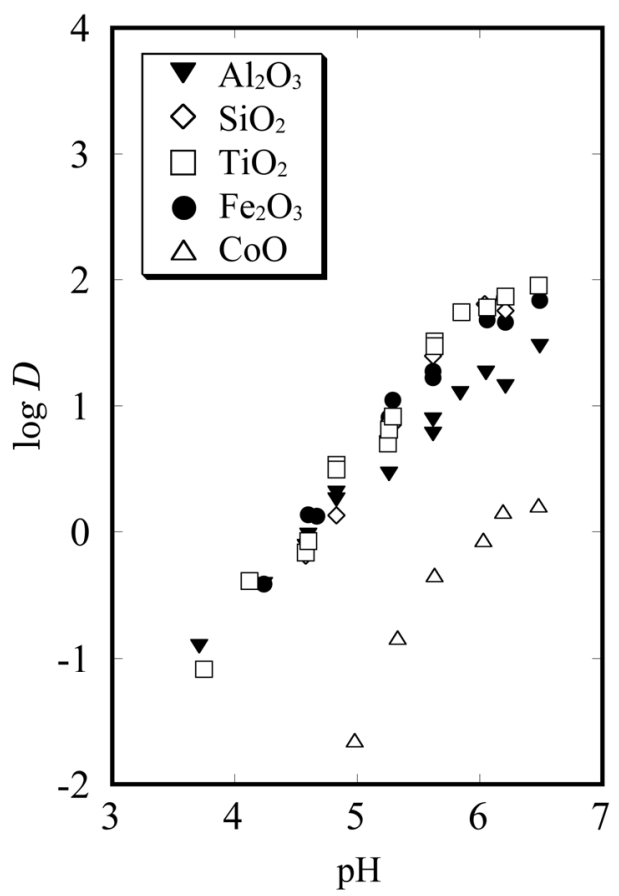

Figure 3. Plots of $\log D$ as a function of $\mathrm{pH}$ for adsorption of $\mathrm{Be}^{2+}$ onto oxide nanoparticles in water

Here, $[\mathrm{X}]$ and $[\mathrm{X}]_{\mathrm{s}}$ denote the concentration of a material $\mathrm{X}$ in the aqueous phase $\left(\mathrm{mol} / \mathrm{dm}^{3}\right)$ and that in the nanoparticle phase (mol/g), respectively. The symbol $n$ represents the number of the surface $-\mathrm{O}-$ groups bound to one $\mathrm{Be}^{2+}$ ion. In the $\mathrm{pH}$ range of the present experimental conditions, the main aqueous species of beryllium(II) are $\mathrm{Be}^{2+}, \mathrm{Be}(\mathrm{OH})^{+}$, and $\mathrm{Be}(\mathrm{OH})_{2}$, as expected from the hydrolysis constants, $K_{1}=\left[\mathrm{Be}(\mathrm{OH})^{+}\right]\left[\mathrm{H}^{+}\right] /\left[\mathrm{Be}^{2+}\right]=10^{-5.7}$ and $\beta_{2}=\left[\mathrm{Be}(\mathrm{OH})_{2}\right]\left[\mathrm{H}^{+}\right]^{2} /$ $\left[\mathrm{Be}^{2+}\right]=10^{-11.68}$ (Schwarzenbach \& Wenger, 1969; Chinea et al., 1997). Assuming that $\mathrm{Be}^{2+}$ is mainly concerned with the surface complexation, $D$ can be expressed as follows.

$$
\begin{aligned}
D= & {\left[(>\mathrm{S}-\mathrm{O})_{\mathrm{n}} \mathrm{Be}^{(2-n)+}\right]_{\mathrm{s}} /\left(\left[\mathrm{Be}^{2+}\right]+\left[\mathrm{Be}(\mathrm{OH})^{+}\right]+\left[\mathrm{Be}(\mathrm{OH})_{2}\right]\right) } \\
& =\left\{\beta_{\mathrm{s}, n}[>\mathrm{S}-\mathrm{OH}]_{\mathrm{s}}^{n} /\left[\mathrm{H}^{+}\right]^{n}\right\} /\left(1+K_{1} /\left[\mathrm{H}^{+}\right]+\beta_{2} /\left[\mathrm{H}^{+}\right]^{2}\right) .
\end{aligned}
$$

The following equation is derived from Equation (4).

$$
\log D+\log \left(1+K_{1} /\left[\mathrm{H}^{+}\right]+\beta_{2} /\left[\mathrm{H}^{+}\right]^{2}\right)=\log \left\{\beta_{\mathrm{s}, n}[>\mathrm{S}-\mathrm{OH}]_{\mathrm{s}}^{n} /\left[\mathrm{H}^{+}\right]^{n}\right\} .
$$

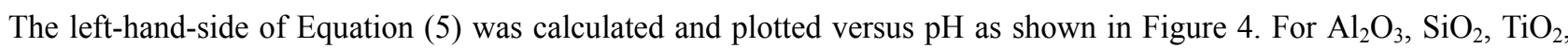
and $\mathrm{Fe}_{2} \mathrm{O}_{3}$, the slopes of the plots change between 1 and 2, indicating that $n=1$ and 2. Only for CoO, the slope is between 2 and 3; this suggests that $n=2$ and 3, which is the same result as for $\mathrm{CuO}$ (Bessho et al., 2014). As mentioned above, most of the hydroxyl groups are undissociated in the $\mathrm{pH}$ region where the adsorption experiments were conducted. Hence, using the hydroxyl group concentrations $\left([>\mathrm{S}-\mathrm{OH}]_{\mathrm{s}}\right)$ shown in Table 1 , the values of $\beta_{\mathrm{s}, n}$ were obtained by nonlinear least squares fitting according to Equation (5). The values are summarized in Table 2. The lines in Figure 4 are the regression curves and fit well with the experimental data.

The sequences of the $\beta_{\mathrm{s}, 1}, \beta_{\mathrm{s}, 2}$, and $\beta_{\mathrm{s}, 3}$ values are $\mathrm{Fe}_{2} \mathrm{O}_{3}>\mathrm{TiO}_{2} \approx \mathrm{Al}_{2} \mathrm{O}_{3}>\mathrm{SiO}_{2}\left(\beta_{\mathrm{s}, 1}\right), \mathrm{Fe}_{2} \mathrm{O}_{3}>\mathrm{TiO}_{2}>\mathrm{SiO}_{2}>\mathrm{Al}_{2} \mathrm{O}_{3}>>$ $\mathrm{CoO} \approx \mathrm{CuO}\left(\beta_{\mathrm{s}, 2}\right)$, and $\mathrm{CuO}>\mathrm{CoO}\left(\beta_{\mathrm{s}, 3}\right)$, respectively. It is expected that the oxide having a positive zeta potential is unfavorable to the complexation with the $\mathrm{Be}^{2+}$ cation. However, $\mathrm{Al}_{2} \mathrm{O}_{3}$ (positively charged) have a much larger $\beta_{\mathrm{s}, 2}$ value than $\mathrm{CoO}$ and $\mathrm{CuO}$ (nearly neutral). In addition, when the $n$ value is 2 , the surface charge does not change in the complexation reaction of Equation (2). Therefore, it appears that the zeta potential of the oxide nanoparticles is not a dominant factor determining their reactivity for $\mathrm{Be}^{2+}$.

From thermodynamic viewpoint, the complexation reaction of Equation (2) can be considered to consist of the following two equilibrium processes.

$$
\begin{gathered}
>\mathrm{S}-\mathrm{OH} \rightleftarrows>\mathrm{S}-\mathrm{O}^{-}+\mathrm{H}^{+}, \\
\mathrm{Be}^{2+}+n>\mathrm{S}-\mathrm{O}^{-} \rightleftarrows(>\mathrm{S}-\mathrm{O})_{n} \mathrm{Be}^{(2-n)+} .
\end{gathered}
$$

These equations show the deprotonation of the surface hydroxyl group (Equation (6)) and the bonding of the negatively charged deprotonated site to $\mathrm{Be}^{2+}$ (Equation (7)), respectively. The reaction of Equation (6) should be facilitated with 


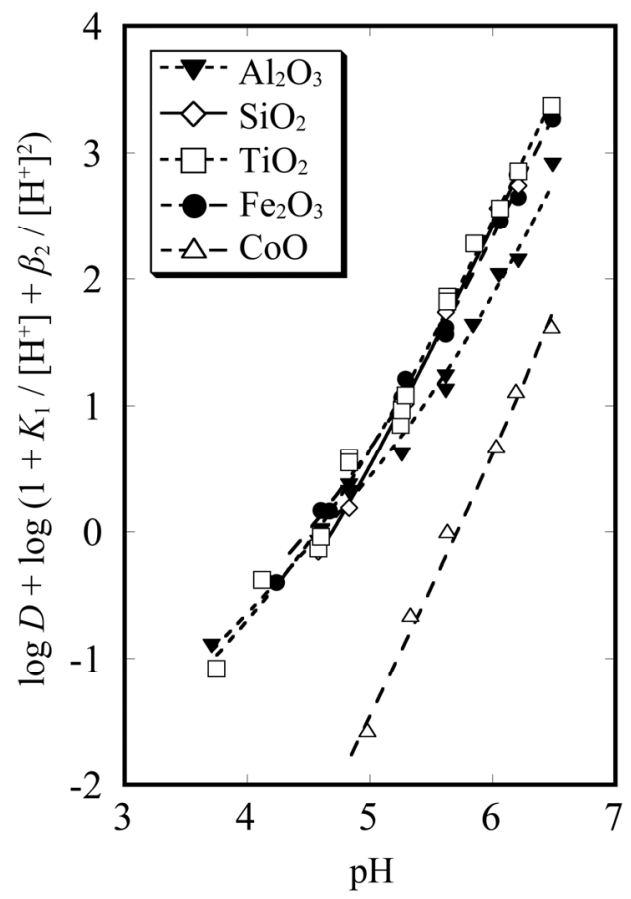

Figure 4. Plots of $\left\{\log D+\log \left(1+K_{1} /\left[\mathrm{H}^{+}\right]+\beta_{2} /\left[\mathrm{H}^{+}\right]^{2}\right)\right\}$ as a function of $\mathrm{pH}$. The lines are the regression curves according to Equation (5).

Table 2. Complexation constants of $\mathrm{Be}^{2+}$ with surface hydroxyl groups of various oxide nanoparticles in water at $25{ }^{\circ} \mathrm{C}$

\begin{tabular}{cccc}
\hline & $\log \beta_{\mathrm{s}, 1}$ & $\log \beta_{\mathrm{s}, 2}$ & $\log \beta_{\mathrm{s}, 3}$ \\
\hline $\mathrm{Al}_{2} \mathrm{O}_{3}$ & $-0.69 \pm 0.04$ & $-2.35 \pm 0.06$ & \\
$\mathrm{SiO}_{2}$ & $-1.17 \pm 0.14$ & $-1.71 \pm 0.04$ & \\
$\mathrm{TiO}_{2}$ & $-0.62 \pm 0.09$ & $-1.28 \pm 0.05$ & \\
$\mathrm{Fe}_{2} \mathrm{O}_{3}$ & $-0.27 \pm 0.06$ & $-1.10 \pm 0.04$ & \\
$\mathrm{CoO}$ & & $-3.99 \pm 0.08$ & $-6.92 \pm 0.38$ \\
$\mathrm{CuO}$ & & $-4.03^{\mathrm{a}}$ & $-5.17^{\mathrm{a}}$ \\
\hline
\end{tabular}

a. Bessho et al., 2014.

decreasing charge density of the oxygen atom of $>\mathrm{S}-\mathrm{OH}$. If the bond between $>\mathrm{S}-\mathrm{O}^{-}$and $\mathrm{Be}^{2+}$ is governed by an electrostatic interaction, the reaction of Equation (7) should also depend on the charge density of the oxygen atom of $>\mathrm{S}^{-} \mathrm{O}^{-}$; in this case, an increase in the oxygen charge density facilitates the reaction of Equation (7). Therefore, the reactions of Equations (6) and (7) are oppositely affected by the charge density of the oxygen atom which should decrease with increasing electronegativity of the metal (or $\mathrm{Si}$ ) composing the oxide.

Tanaka and Ozaki reported the electronegativity $\left(X_{i}\right)$ of the lattice metal ions of oxides (Tanaka \& Ozaki, 1967). The $X_{i}$ is given by the following equation.

$$
X_{i}=(1+2 Z) X_{0},
$$

where $Z$ and $X_{0}$ are the valence and Pauling's electronegativity, respectively. The $X i$ values calculated by Equation (8) were used for evaluating activity of catalyst (Tanaka \& Ozaki, 1968; Imelik, Naccache, Coudurier, Taarit, \& Vedrine, 1985 ) and $\mathrm{Co}^{2+}$ adsorption properties of metal oxides (Tamura, Katayama, \& Furuichi, 1997). For the oxides examined in this study, the $X_{i}$ values calculated are as follows: in increasing order of $X_{\mathrm{i}}, \mathrm{CoO}\left(X_{\mathrm{i}}=9.0\right), \mathrm{CuO}\left(X_{\mathrm{i}}=9.5\right), \mathrm{Al}_{2} \mathrm{O}_{3}\left(X_{\mathrm{i}}\right.$ $=10.5), \mathrm{Fe}_{2} \mathrm{O}_{3}\left(X_{\mathrm{i}}=12.6\right), \mathrm{TiO}_{2}\left(X_{\mathrm{i}}=13.5\right)$, and $\mathrm{SiO}_{2}\left(X_{\mathrm{i}}=16.2\right)$. In Figure 5, the $\log \beta_{\mathrm{s}, n}(n=1,2$, and 3) values are plotted against the $X_{\mathrm{i}}$ value. The $\log \beta_{\mathrm{s}, n}$ values increase with an increase in $X_{\mathrm{i}}$ from $\mathrm{CoO}$ to $\mathrm{Fe}_{2} \mathrm{O}_{3}$. This result suggests that the complexation of $\mathrm{Be}^{2+}$ with the oxide nanoparticles (Equation (2)) is governed by the deprotonation of $>\mathrm{S}-\mathrm{OH}$ 


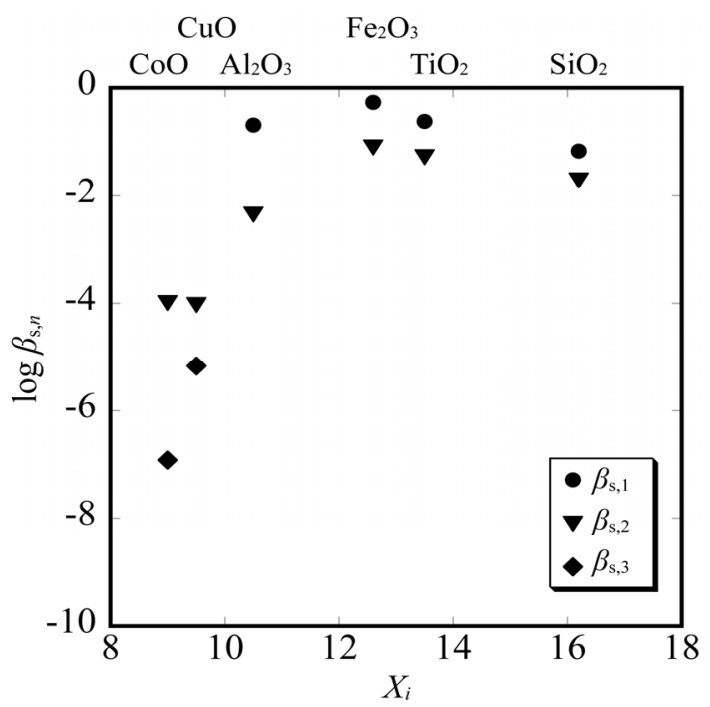

Figure 5. Plots of complexation constants of $\mathrm{Be}^{2+}$ with hydroxyl groups on oxide surface as a function of electronegativity of the metal (or $\mathrm{Si}$ ) composing the oxide

(Equation (6)) than the bonding of $>\mathrm{S}^{-} \mathrm{O}^{-}$to $\mathrm{Be}^{2+}$ (Equation (7)). A similar result was reported for the complexation of $\mathrm{Co}^{2+}$ with metal oxides (Tamura et al., 1997) However, in the higher $X_{\mathrm{i}}$ region $\left(\mathrm{Fe}_{2} \mathrm{O}_{3}, \mathrm{TiO}_{2}\right.$, and $\left.\mathrm{SiO}_{2}\right)$, the $\beta_{\mathrm{s}, n}$ values of $\mathrm{Be}^{2+}$ decrease with an increase in $X_{\mathrm{i}}$, indicating that the contribution of the coordination of $>\mathrm{S}-\mathrm{O}^{-}$to $\mathrm{Be}^{2+}$ exceeds that of the deprotonation of $>\mathrm{S}-\mathrm{OH}$. This may reflect the relatively strong interaction between the small $\mathrm{Be}^{2+}$ ion and $>\mathrm{S}-\mathrm{O}^{-}$. The appearance of the maximum in the complexation constant at $X_{\mathrm{i}} \approx 13\left(\mathrm{Fe}_{2} \mathrm{O}_{3}\right)$ is a result of the competition of the two different processes (Equations (6) and (7)).

Although the complexation abilities of $\mathrm{CoO}$ and $\mathrm{CuO}$ are smaller as compared to those of the other oxides, only $\mathrm{CoO}$ and $\mathrm{CuO}$ form $(>\mathrm{S}-\mathrm{O})_{3} \mathrm{Be}^{-}$complexes on the surface. In order that three $>\mathrm{S}-\mathrm{O}^{-}$can bind to a $\mathrm{Be}^{2+}$ ion, a close positioning of the $>\mathrm{S}-\mathrm{OH}$ sites is necessary. So we evaluated the surface hydroxyl group density (the amount of hydroxyl groups per unit area of the surface) under some assumptions. Assuming that the nanoparticles in water comprise a hexagonal close-packed array of uniform spherical particles which have a diameter equal to the average particle size of the dry nanoparticles, the packing efficiency of the spheres is 0.74 . By considering the packing efficiency, the surface hydroxyl group density can be estimated from the data in Table 1 (Bessho et al., 2014). The densities (unit: $\mathrm{mol} / \mathrm{m}^{2}$ ) are $8 \times 10^{-6}, 8 \times 10^{-6}, 1 \times 10^{-5}, 1 \times 10^{-5}, 3 \times 10^{-5}$, and $2 \times 10^{-5}$ for $\mathrm{Al}_{2} \mathrm{O}_{3}, \mathrm{SiO}_{2}, \mathrm{TiO}_{2}, \mathrm{Fe}_{2} \mathrm{O}_{3}$, $\mathrm{CoO}$, and $\mathrm{CuO}$, respectively. These values are comparable, in the order of magnitude, to the literature values (Tamura, Mita, Tanaka, \& Ito, 2001). The surface hydroxyl group density we calculated suggests that the surface hydroxyl groups are more closely positioned on the $\mathrm{CoO}$ and $\mathrm{CuO}$ nanoparticles than on the other oxides. The density, however, may also depend on the preparation method of the oxide.

\section{Conclusion}

The adsorption behavior of $\mathrm{Be}^{2+}$ onto nanoparticles of several metal oxides and $\mathrm{SiO}_{2}$ in water was quantitatively explained on the basis of the complexation model between $\mathrm{Be}^{2+}$ and surface hydroxyl groups of the oxides. In general, one $\mathrm{Be}^{2+}$ ion react with one or two hydroxyl groups on the oxide surface. The complexation constants were found to vary with the electronegativity of the metal (or $\mathrm{Si}$ ) composing the oxide as follows: $\mathrm{CoO} \approx$ or $<\mathrm{CuO}<\mathrm{Al}_{2} \mathrm{O}_{3}<\mathrm{Fe}_{2} \mathrm{O}_{3}>$ $\mathrm{TiO}_{2}>\mathrm{SiO}_{2}$. The fact that the complexation constants show maximum values for $\mathrm{Fe}_{2} \mathrm{O}_{3}$ can be explained based on the opposite effects of the charge density of the oxygen atom on the deprotonation of the surface hydroxyl groups and on the binding of the negatively charged oxygen atoms to $\mathrm{Be}^{2+}$.

As can be seen from Equation (4), the distribution ratio of $\mathrm{Be}^{2+}$ between the nanoparticle phase and the aqueous solution phase depends not only on the surface complexation constants but also on the hydroxyl group concentration (amount of $-\mathrm{OH}$ sites per unit mass of the particles). For example, the higher distribution ratio of $\mathrm{Be}^{2+}$ for $\mathrm{CuO}$ than for $\mathrm{CoO}$ is explained in terms of the higher hydroxyl group concentration of $\mathrm{CuO}$. Nanoparticles of the oxides, which have extremely large surface area-to-weight ratios, exhibit high adsorption ability for $\mathrm{Be}^{2+}$ because of their high hydroxyl group concentration. The distribution ratio can be easily estimated from the complexation constants and the hydroxyl group concentration. These findings will provide an effective solution for the removal of ${ }^{7} \mathrm{Be}$ produced in cooling water systems for high-energy accelerators, and also be applicable to adsorption of other metal ions on metal oxide nanoparticles. 


\section{Acknowledgments}

This research was partially supported by a Grant-in-Aid for Scientific Research (No. 26410145) from the Ministry of Education, Culture, Sports, Science and Technology of Japan.

\section{References}

Al-Saad, K. A., Amr, M. A., Hadi, D. T., Arar, R. S., AL-Sulaiti, M. M., Abdulmalik, T. A., ... Kwak, J. C. (2012). Iron oxide nanoparticles: applicability for heavy metal removal from contaminated water. Arab Journal of Nuclear Sciences and Applications, 45(2), 335-346.

http://www.esnsa-eg.com/download/researchFiles/Heavy_metal_removal_nanoparticles_updated.pdf

Balistrieri, L., Brewer, P. G., \& Murray, J. W. (1981). Scavenging residence times of trace metals and surface chemistry of sinking particles in the deep ocean. Deep Sea Research Part A. Oceanographic Research, 28(2), 101-121. https://doi.org/10.1016/0198-0149(81)90085-6

Bessho, K., Hagiwara, M., Matsumura, H, Kitagawa, J., Takahashi, K., Takahashi, A., ... Yamada, Y. (2015a). Production of Radionuclides in the Cooling Water for Electromagnetic Horns at the J-PARC Neutrino Experimental Facility. JPS Conference Proceedings, 8, 051005. https://doi.org/10.7566/JPSCP.8.051005

Bessho, K., Kanaya, N., Shimada, S., Katsuta, S., \& Monjushiro, H. (2014). Adsorption behavior of beryllium(II) on copper-oxide nanoparticles dispersed in water: A model for ${ }^{7} \mathrm{Be}$ colloid formation in the cooling water for electromagnets at high-energy accelerator facilities. Analytical Sciences, 30(11), 1069-1074. https://doi.org/10.2116/analsci.30.1069

Bessho, K., Matsumura, H., Hagiwara, M., Takahashi, K., Takahashi, A., Iwase, H., ... Yamada, Y. (2013). Origin and chemical behaviour of radionuclides observed in the cooling water for magnetic horns at the J-PARC Neutrino Experimental Facility. In Proceedings of the 11th Meeting of the Task-Force on Shielding Aspects of Accelerators, Targets, and Irradiation Facilities - SATIF-11 (pp. 61-69). Issy-les-Moulineaux, France: OECD Nuclear Energy Agency. https://www.oecd-nea.org/science/pubs/2013/7157-satif-11.pdf

Bessho, K., Matsumura, H., Kinoshita, N., Masumoto, K., Monjushiro, H., Taira, M., ... Katsuta, S. (2010). Analysis of colloidal species formed in the cooling water of high-energy accelerator facilities. In K. Bessho, \& T. Miura (Eds.), KEK Proceedings 2010-8 (pp. 19-26). Tsukuba, Japan: https://lib-extopc.kek.jp/preprints/PDF/2010/1025/1025008.pdf

Bessho, K., Matsumura, H., Takahashi, A., \& Masumoto, K. (2015b). Behavior of radionuclides induced in cooling water for electromagnets at the $12 \mathrm{GeV}$ proton accelerator facility. Journal of Radioanalytical and Nuclear Chemistry, 303(3), 1719-1725. https://doi.org/10.1007/s10967-014-3705-x

Brown, G. E., Jr., \& Parks, G. A. (2001). Sorption of trace elements on mineral surfaces: Modern perspectives from spectroscopic studies, and comments on sorption in the marine environment. Journal of International Geology Review, 43(11), 963-1073. https://doi.org/10.1080/00206810109465060

Cao, C. Y., Qu, J., Yan, W. S., Zhu, J. F., Wu, Z. Y., \& Song, W. G. (2012). Low-cost synthesis of flowerlike $\alpha-\mathrm{Fe}_{2} \mathrm{O}_{3}$ nanostructures for heavy metal ion removal: Adsorption property and mechanism. Langmuir, 28(9), 4573-4579. https://doi.org/10.1021/la300097y

Carpenter, M. A., Mathur, S., \& Kolmakov, A. (2013). Metal oxide nanomaterials for chemical sensors. New York, NY: Springer. https://doi.org/10.1007/978-1-4614-5395-6

Chinea, E., Dominguez, S., Mederos, A., Brito, F., Sanchez, A., Ienco, A., \& Vacca, A. (1997). Hydrolysis of beryllium(II) in DMSO: $\mathrm{H}_{2} \mathrm{O}$. Main Group Metal Chemistry, 20(1) 11-18. https://doi.org/10.1515/MGMC.1997.20.1.11

Fernández-García, M., Martínez-Arias, A., Hanson, J. C., \& Rodríguez, J. A. (2004). Nanostructured oxides in chemistry: Characterization and properties. Chemical Reviews, 104(9), 4063-4104.

https://doi.org/10.1021/cr030032f

Hua, M., Zhang, S., Pan, B., Zhang, W., Lv, L., \& Zhang, Q. (2012). Heavy metal removal from water/wastewater by nanosized metal oxides: A review. Journal of Hazardous Materials, 211-212, 317-331. https://doi.org/10.1016/j.jhazmat.2011.10.016

Imelik, B., Naccache, C., Coudurier, G., Taarit, Y. B., \& Vedrine, J. C. (Eds.). (1985). Catalysis by acids and bases (Vol. 20, 1st ed.). Amsterdam, Netherlands: Elsevier.

Itoh, S., Miura, T., Furusaka, M., Yasui, S., Ogawa, Y., Kiyanagi, Y., ... Iijima, K. (1998). Behavior of ${ }^{7}$ Be in the moderator cooling system at the pulsed neutron source, KENS. In J. M. Carpenter and C. A. Tobin (Eds.), Proceedings of the 14th Meeting of the International Collaboration on Advanced Neutron Sources (ICANS-XIV) (pp. 823-828). Argonne, IL: Argonne National Laboratory. 
http://www.neutronresearch.com/parch/1998/01/199801008230.pdf

Itoh, S., Miura, T., Furusaka, M., Yasui, S., Ogawa, Y., Kiyanagi, Y., ... Iijima, K. (1999). Activation of water in the cooling system at the pulsed spallation neutron source, KENS. Journal of Physics and Chemistry of Solids, 60(8-9), 1557-1559. https://doi.org/10.1016/S0022-3697(99)00172-9

Linsebigler, A. L., Lu, G., \& Yates, J. T., Jr. (1995). Photocatalysis on $\mathrm{TiO}_{2}$ surfaces: Principles, mechanisms, and selected results. Chemical Reviews, 95(3), 735-758. https://doi.org/10.1021/cr00035a013

Mahdavi, S., Jalali, M., \& Afkhami, A. (2012). Removal of heavy metals from aqueous solutions using $\mathrm{Fe}_{3} \mathrm{O}_{4}$, $\mathrm{ZnO}$, and $\mathrm{CuO}$ nanoparticles. In M. S. Diallo, N. A. Fromer, \& M. S. Jhon (Eds.), Nanotechnology for Sustainable Development (pp. 171-188). Cham, Switzerland: Springer. https://doi.org/10.1007/978-3-319-05041-6_14

Matsumura, H., Kinoshita, N., Toyoda, A., Masumoto, K., Bessho, K., Hagiwara, M., \& Yamanoi, Y. (2009). Adsorption behavior of radionuclides on ion-exchange resin from cooling water for the $\mathrm{K} 2 \mathrm{~K}$ target and magnetic horns. Nuclear Technology, 168(3), 979-983. https://doi.org/10.13182/NT168-979

Matsumura, H., Sekimoto, S., Yashima, H., Toyoda, A., Kasugai, Y., Matsuda, N., ... Vaziri, K. (2014). Radionuclides in the cooling water systems for the NuMI beamline and the antiproton production target station at Fermilab. Progress in Nuclear Science and Technology, 4, 372-375. https://doi.org/10.15669/pnst.4.372

Poizot, P., Laruelle, S., Grugeon, S., Dupont, L., \& Tarascon, J. M. (2000) Nano-sized transition-metal oxides as negative-electrode materials for lithium-ion batteries. Nature, 407, 496-499. https://doi.org/10.1038/35035045

Rahnemaie, R., Hiemstra, T., \& Van Riemsdijk, W. H. (2006). Inner- and outer-sphere complexation of ions at the goethite-solution interface. Journal of Colloid and Interface Science, 297(2), 379-388. https://doi.org/10.1016/j.jcis.2005.11.003

Sadegh, H., Ali, G. A. M., Gupta, V. K., Makhlouf, A. S. H., Shahryari-ghoshekandi, R., Nadagouda, M. N., ... Megiel, E. (2017). The role of nanomaterials as effective adsorbents and their applications in wastewater treatment. Journal of Nanostructure in Chemistry, 7(1), 1-14. https://doi.org/10.1007/s40097-017-0219-4

Schilz, J. R., Reddy, K. J., Nair, S., Johnson, T. E., Tjalkens, R. B., Krueger, K. P., \& Clark, S. (2015). Removal of trace elements by cupric oxide nanoparticles from uranium in situ recovery bleed water and its effect on cellviability. Journal of Visualized Experiments, (100), e52715. https://doi.org/10.3791/52715

Schwarzenbach, G., \& Wenger, H. (1969). Die deprotonierung von metall-aquoionen I.: Be·aq ${ }^{2+}$ solvatations-isomerie. Helvetica Chimica Acta, 52(3), 644-665. https://doi.org/10.1002/hlca.19690520313

Stumm, W., Westall, J. C., Parsons, R., Marinsky, J. A., Shindler, P. W., Motschi, H., ... Fyfe, W. S. (1987). Aquatic surface chemistry-chemical processes at the particle-water interface. New Yorf, NY: Wiley-Interscience.

Sverjensky, D. A. (2006). Prediction of the speciation of alkaline earths adsorbed on mineral surfaces in salt solutions. Geochimica et Cosmochimica Acta, 70(10), 2427-2453. https://doi.org/10.1016/j.gca.2006.01.006

Taman, R., Ossman, M. E., Mansour, M. S., \& Farag, H. A. (2015). Metal oxide nano-particles as an adsorbent for removal of heavy metals. Advanced Chemical Engineering, 5(3), 1000125. https://doi.org/10.4172/2090-4568.1000125

Tamura, H., Katayama, N., \& Furuichi, R. (1997). The $\mathrm{Co}^{2+}$ adsorption properties of $\mathrm{Al}_{2} \mathrm{O}_{3}, \mathrm{Fe}_{2} \mathrm{O}_{3}, \mathrm{Fe}_{3} \mathrm{O}_{4}, \mathrm{TiO}_{2}$, and $\mathrm{MnO}_{2}$ evaluated by modeling with the Frumkin isotherm. Journal of Colloid and Interface Science, 195(1), 192-202. https://doi.org/10.1006/jcis.1997.5148

Tamura, H., Mita, K., Tanaka, A., \& Ito, M. (2001). Mechanism of hydroxylation of metal oxide surfaces. Journal of Colloid and Interface Science, 243(1), 202-207. https://doi.org/10.1006/jcis.2001.7864

Tanaka, K., \& Ozaki, A. (1967). Acid-base properties and catalytic activity of solid surfaces. Journal of Catalysis, 8(1), 1-7. https://doi.org/10.1016/0021-9517(67)90274-6

Tanaka, K., \& Ozaki, A. (1968). The catalytic activity of sulfate in the decomposition of formic acid. Bulletin of the Chemical Society of Japan, 41(11), 2812-2813. https://doi.org/10.1246/bcsj.41.2812

Vélez, E., Campillo, G. E., Morales, G., Hincapié, C., Osorio, J., Arnache, O., ... Jaramillo, F. (2016). Mercury removal in wastewater by iron oxide nanoparticles. Journal of Physics: Conference Series, 687, 012050. https://doi.org/10.1088/1742-6596/687/1/012050

\section{Copyrights}

Copyright for this article is retained by the author(s), with first publication rights granted to the journal.

This is an open-access article distributed under the terms and conditions of the Creative Commons Attribution license (http://creativecommons.org/licenses/by/4.0/). 